\title{
One-Pot Green Synthesis of Highly Reduced Graphene Oxide Decorated with Silver Nanoparticles
}

(Sintesis Mesra Alam Satu Pot oleh Grafin Oksida Terkurang Tinggi

yang Dihiaskan dengan Zarah Nano Argentum)

\author{
Nur Suhaili AbD AzIz, Muhammad Khairullah Nor AzMi \& Abdul Manaf Hashim*
}

\begin{abstract}
A one-pot green sonochemical process assisted by ascorbic acid as the reducing agent to produce highly reduced graphene oxide ( $r G O)$ decorated with silver nanoparticles (AgNPs) is demonstrated. A complete removal of oxygencontaining group in the GO sheets was confirmed by no observation of the peak corresponds to $C-O, C=O$ and $-O H$ bond. The unexpected decrease of peak intensity corresponds to $s p^{2}$ hybridized $C=C$ group is explained by a so-called bond polarity effect. The peak observed at $400 \mathrm{~nm}$ seems to show the presence of AgNPs and the red shifting of $C=C$ peak to $270 \mathrm{~nm}$ after the introduction of ascorbic acid indicates the formation of highly reduced GO. The increase of AgNPs size and the crumpled silk-like morphology after the introduction of ascorbic acid also indicate the aggressive reduction of both AgNPs and GO. The increase of $I_{D} / I_{G}$ ratio after the introduction of ascorbic acid seems to indicate the increase of the number of small $s p^{2}$ domains, the presence of unrepaired defects and the restoration of the sp ${ }^{2}$ network. This work provides the promising green sonochemical approach by utilizing non-toxic and environmental-friendly reducing agent to produce highly reduced GO decorated with AgNPs for various applications.
\end{abstract}

Keywords: Reduced graphene oxide; silver nanoparticle; sonochemical method

\section{ABSTRAK}

Proses sonokimia satu pot mesra alam yang dibantu oleh asid askorbik sebagai agen menurunan telah didemonstrasi untuk menghasilkan grafin oksida (rGO) terkurang tinggi yang dihiaskan dengan zarah nano argentum (AgNPs). Pembuangan yang lengkap bagi kumpulan yang mempunyai oksigen pada lembaran Go disahkan oleh tiadanya puncak kepunyaan $\mathrm{C}-\mathrm{O}, \mathrm{C}=\mathrm{O}$ dan ikatan $-\mathrm{OH}$. Pengurangan keamatan puncak yang mengejutkan pada kumpulan $\mathrm{C}=\mathrm{C}$ sp ${ }^{2}$ terhibrid dapat diterangkan oleh yang dipanggil kesan polariti ikatan. Puncak yang dilihat pada $400 \mathrm{~nm}$ membuktikan kehadiran AgNPs dan peralihan ke kanan oleh puncak $C=C$ pada $270 \mathrm{~nm}$ selepas pengenalan kepada asid askorbik menunjukkan GO telah terturun dengan tinggi. Peningkatan saiz AgNPs dan morfologi seperti sutera renyuk selepas pengenalan kepada asid askorbik juga menunjukkan penurunan yang agresif pada kedua AgNPs dan GO. Peningkatan nisbah $I_{D} / I_{G}$ selepas pengenalan kepada asid asorbik kelihatan menunjukkan peningkatan domain sp ${ }^{2}$ yang kecil dengan kehadiran kecacatan yang tidak dibaiki dan pemulihan rangkaian $s^{2}$. Kertas ini memberikan pendekatan sonokimia yang mesra alam dengan pendekatan menggunakan agen pengurangan yang tidak toksik dan mesra alam sekitar untuk menghasilkan pengurangan GO yang tinggi dihiasi dengan AgNPs untuk pelbagai aplikasi.

Kata kunci: Kaedah sonokimia; penurunan grafin oksida; zarah nano argentum

\section{INTRODUCTION}

Graphene is a two-dimensional (2D) one-atom-thick sheet of $\mathrm{sp}^{2}$-bonded carbon atoms which has unique electronic, mechanical and thermal properties. Thus, it is very promising for many potential applications in nanoelectronic devices, sensors and supercapacitors (Golsheikh et al. 2014). Since the past decade, due to its large 2D surface area and those excellent properties, graphene has been considered as an attractive matrix of nanocomposites for the integration with the metal nanoparticles (NPs) in realizing further novel and superior properties for various specific applications such as in fuel cell, electrochemical energy storage and electrochemical sensors (Dinh et al. 2014). It is worth noting that the graphene flakes produced by the chemical exfoliation is the cheapest and practical way. However, such method commonly generates graphene oxide (GO) instead of pure graphene. Therefore, for the realization of high performance device, the produced GO flakes need to be reduced where the functional groups on the GO are eliminated so that the conductivity of GO can be restored to the common level of graphene.

Recently, silver (Ag) NPs on reduced graphene oxide (rGO) has been shown to provide larger electrochemically active surface areas to effectively accelerate the electron transfer between the electrode and detection molecules, leading to the rapid and sensitive current response (Pumera 2010).AgNPs-rGO composite has a potential to be applied for sensing application such as for ammonia, mercury, 
glucose and hydrogen peroxide sensing (Cui et al. 2013; Golsheikh et al. 2014; Zhang et al. 2012). Furthermore, composite of AgNPs and rGO is also good to be applied as the electrode in solar cell due to its excellent electrical conductivity and anti-reflection coating (Zhou et al. 2013). Therefore, the effort to produce the AgNPs-rGO that can possess two important properties; excellent coating uniformity when is dispersed on the substrate; and highly reduction, becomes necessary. Recently, AgNPs-rGO composite is synthesized using the sonochemical and chemical approaches (Golsheikh et al. 2014; Sahu et al. 2013). Unfortunately, the reduction rate of the composite is still low. Most literatures report the application of multi processes or steps in order to further increase the reduction of the composite, for example, by adding an annealing process (Cui et al. 2013; Zhou et al. 2013). This seems to make the entire process becomes complicated.

In this work, we report a one-pot green facile synthesis of highly reduced GO by adding ascorbic acid in an aqueous solution containing diammine silver (I) hydroxide complex $\left(\left[\mathrm{Ag}\left(\mathrm{NH}_{3}\right)_{2}\right] \mathrm{OH}\right)$ and $\mathrm{GO}$ to further enhance the reduction by a sonochemical process.

\section{EXPERIMENTAL DETAILS}

GO was prepared using a traditional simplified Hummers' method (Huang 2011; Norhakim et al. 2014). Graphite is oxidized to form GO, which was then reduced to become rGO in this work. Oxidation of graphite is a common method to produce graphene since each carbon layer or graphene sheet in graphite is attracted by weak van der Waals forces (Zacharia et al. 2004). Oxidation treatment helps to increase the interlayer distance between graphene sheet in graphite before an exfoliation by water intercalation takes place. Here, the oxidation of graphite was done in a mixture of sulfuric acid $\left(\mathrm{H}_{2} \mathrm{SO}_{4}\right)$, phosphoric acid $\left(\mathrm{H}_{3} \mathrm{PO}_{4}\right)$, graphite flakes and potassium permanganate $\left(\mathrm{KMnO}_{4}\right)$ using a magnetic stirrer. This one-pot mixture was stirred continuously for 3 days to allow the complete oxidation of graphite. After 3 days, the change of color of the mixture from the original color of dark purplish green to dark brown can be seen. Then, $400 \mathrm{~mL}$ of ice and $27 \mathrm{~mL}$ of hydrogen peroxide $\left(\mathrm{H}_{2} \mathrm{O}_{2}\right)$ were added into the container to stop the oxidation process. Here, the bright yellow color of the mixture indicating the formation of GO, can be observed. Next, the synthesized GO was treated with $1 \mathrm{M}$ of hydrochloric acid $(\mathrm{HCl})$ aqueous solution for 3-4 times and followed by deionized (DI) water for 6-7 times.

$\mathrm{Ag}\left(\mathrm{NH}_{3}\right)_{2} \mathrm{OH}$ solution was prepared by adding $1 \mathrm{w} / \mathrm{v} \%$ ammonium hydroxide $\left(\mathrm{NH}_{4} \mathrm{OH}\right)$ solution to $35 \mathrm{mM}$ silver nitrate $\left(\mathrm{AgNO}_{3}\right)$ solution until the complete absence of precipitates was observed. The $\mathrm{Ag}\left(\mathrm{NH}_{3}\right)_{2} \mathrm{OH}$ solution was mixed in an aqueous solution of GO $\left(1.0 \mathrm{mg} \mathrm{mL}^{-1}\right)$. The resulting solution was added with $0.5 \mathrm{~g}$ of ascorbic acid and stirred for $5 \mathrm{~min}$ to ensure the homogeneity. Ascorbic acid is an environmental-friendly reducing agent which is widely used to enhance the reduction of GO (Abulizi et al. 2014; Gao et al. 2010a). Besides, it is also known to have the capability to affect the dimension of AgNPs on GO (Dinh et al. 2014). In order to simultaneously reduce $\mathrm{Ag}^{+}$ ions and GO, the mixture was exposed to acoustic cavitation using ultrasonic horn immersed directly into the mixture at a $60 \%$ of amplitude for $15 \mathrm{~min}$ with a cycle of $3 \mathrm{~s}$ pulse and $5 \mathrm{~s}$ relaxation. Finally, the as-obtained composite (AgNPs/rGO) was centrifuged and washed with DI water for 3 times and kept in DI water (denoted as Ag-rGO-AA). For the comparison, the composite was prepared under the same condition as Ag-rGO-AA without ascorbic acid (denoted as Ag-rGO).

\section{RESULTS AND DISCUSSION}

Figure 1 shows the ATR-FTIR spectra of GO, Ag-rGO and Ag-rGO-AA composites. In the case of GO, the reflectance peaks appear at $1763,1637,1307$ and $1075 \mathrm{~cm}^{-1}$, which corresponds to $\mathrm{C}=\mathrm{O}, \mathrm{C}=\mathrm{C}$, $-\mathrm{OH}$ and $\mathrm{C}-\mathrm{O}$ bond, respectively and the peaks are consistent with the reported spectra (Abulizi et al. 2014). For the Ag-rGO composite, the intensities of those reflectance peaks which corresponds to the functional groups seem to be slightly weaker as compared to GO spectra, indicating the reduction of GO during the synthesis process. However, it is noted that the intensity of reflectance peak which corresponds to $\mathrm{C}=\mathrm{C}$ $\mathrm{sp}^{2}$-hybridized groups $\left(1604 \mathrm{~cm}^{-1}\right)$ in Ag-rGO sample is not significantly strong as expected despite of the increase of the $\mathrm{C}=\mathrm{C}$ group after the reduction process (Vollhardt $\&$ Schore 2009). This phenomenon can be explained by the investigation of a so-called bond polarity effect which will be illustrated in Figure 2 (Vollhardt \& Schore 2009). For Ag-rGO-AA composite, no significant reflectance peak is observed, suggesting a nearly complete removal of O-containing group from the GO sheets by the addition of ascorbic acid. Here, the significant reflectance peak which corresponds to $\mathrm{C}=\mathrm{C} \mathrm{sp}^{2}$-hybridized groups is also not observed as expected despite of the aggressive reduction process, which is commonly reported in other literatures (He et al. 2014; Li et al. 2008; Xu et al. 2015). Figure 2

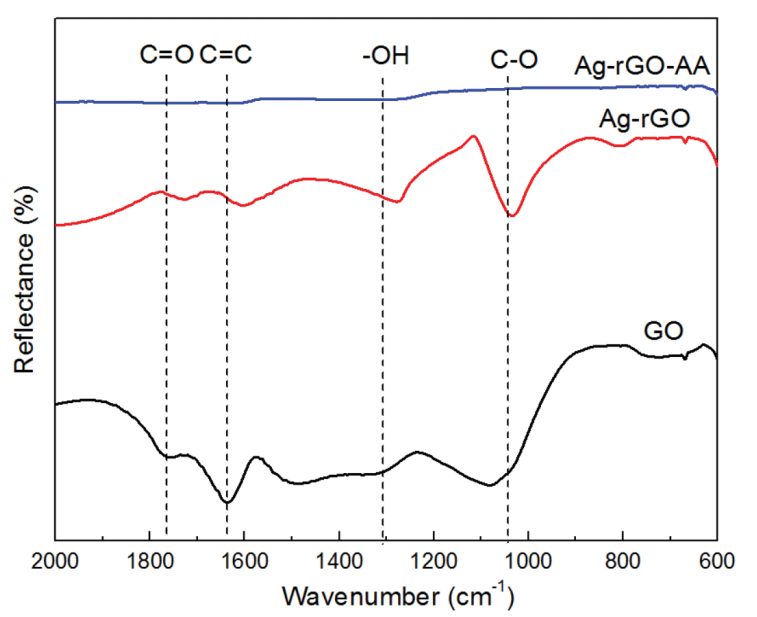

FIGURE 1. ATR-FTIR spectra of GO, Ag-rGO and Ag-rGO-AA nanocomposite 


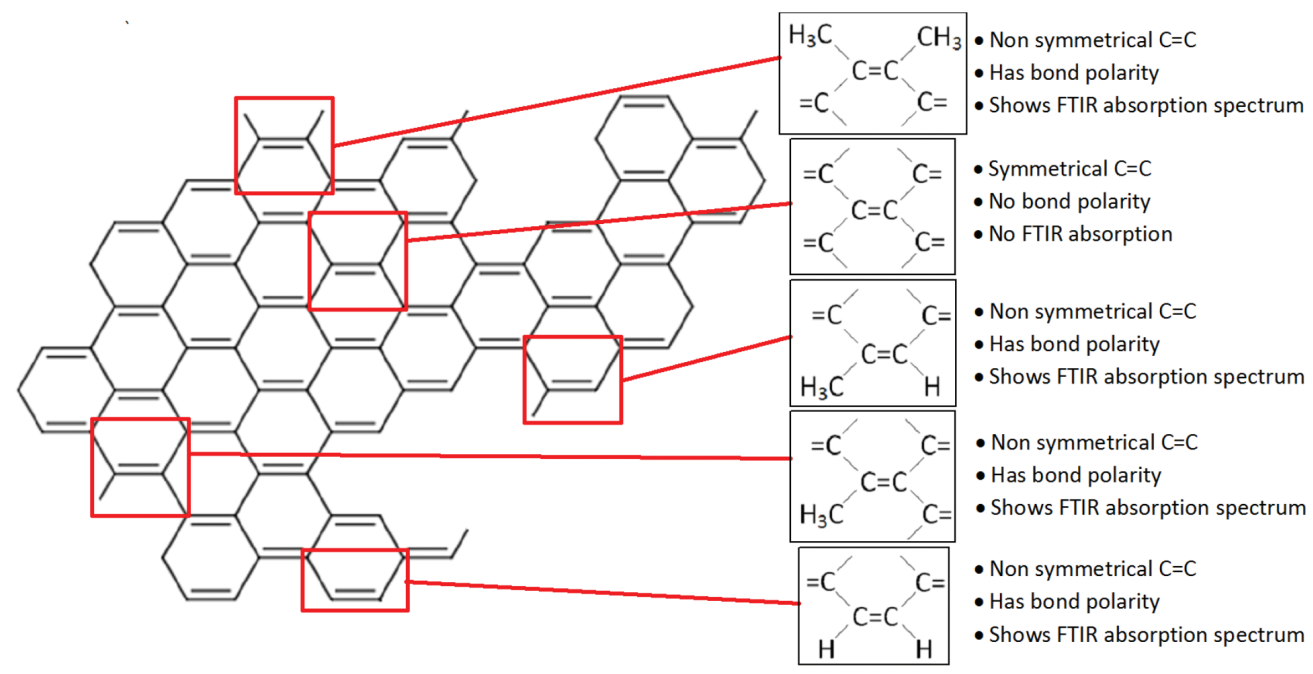

FIGURE 2. Bond polarity effect

illustrates the bond polarity effect of each $\mathrm{C}$ atom bonded in the $\mathrm{C}=\mathrm{C}$ group in graphene sheet. The bond polarity of each $\mathrm{C}$ atom is affected by the electronic charge distribution among the bonded neighboring atoms (Vollhardt \& Schore 2009). Bond polarity shall exist at the sites of structural defects in the graphene sheets (Vollhardt \& Schore 2009). The existence of this bond polarity causes the $\mathrm{C}=\mathrm{C}$ group to be non-symmetrical (Vollhardt \& Schore 2009). Since $\mathrm{C}=\mathrm{C}$ bonds in Ag-rGO-AA are commonly symmetrical, bond polarity on the $\mathrm{C}=\mathrm{C}$ groups should not exist. Thus, the intensity of reflectance peak for $\mathrm{C}=\mathrm{C}$ in $\mathrm{rGO}$ becomes dramatically weak.

Figure 3 shows the UV-vis absorption spectra for GO, Ag-rGO and Ag-rGO-AA composites. The characteristic peak of GO at $228 \mathrm{~nm}$ and a shoulder at $300 \mathrm{~nm}$ indicates the $\pi-\pi^{*}$ transitions of $\mathrm{C}=\mathrm{C}$ bonds and $\mathrm{n}-\pi^{*}$ transitions of $\mathrm{C}=\mathrm{O}$ bonds, respectively (Dinh et al .2014 ). The $\mathrm{C}=\mathrm{C}$ peak of Ag-rGO-AA shifts to a longer wavelength $(271 \mathrm{~nm})$ than GO $(228 \mathrm{~nm})$ and Ag-rGO $(230 \mathrm{~nm})$. This red shifting shows the rapid occurrence of electronic conjugation after the promotion of GO reduction by ascorbic acid (Dinh et al. 2014; Sahu et al. 2013). This can also be seen by the disappearance of the shoulder of $\mathrm{C}=\mathrm{O}$ peak at $300 \mathrm{~nm}$ in Ag-rGO-AA sample (Golsheikh et al. 2014). Such observation of the removal of O-containing groups seems

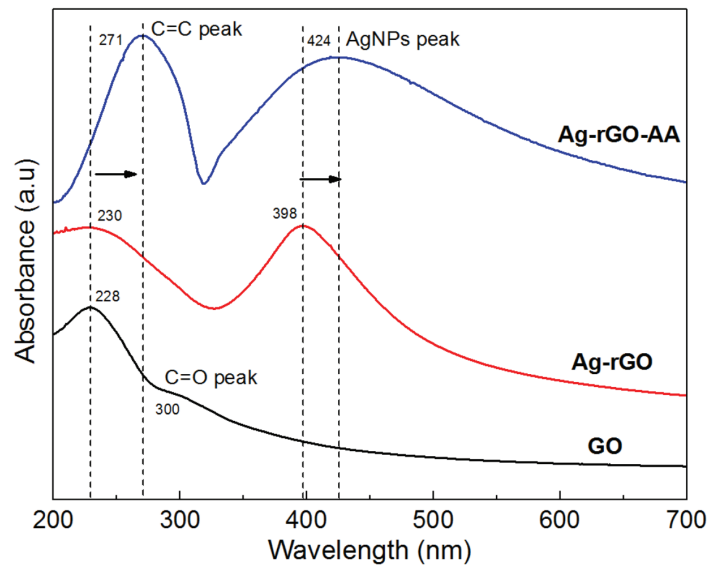

FIGURE 3. UV-vis absorption spectra of GO, Ag-rGO and Ag-rGO-AA nanocomposite

to be consistent with the FTIR spectra. The appearance of the peaks which correspond to AgNPs at $398 \mathrm{~nm}$ in AgrGO and at $424 \mathrm{~nm}$ in Ag-rGO-AA samples indicates the formation of AgNPs (Dinh et al. 2014; Liu et al. 2015). The red shifting of AgNPs peak to $424 \mathrm{~nm}$ in Ag-rGO-AA as compared to Ag-rGO can be related to the increase of AgNPs size (Paramelle et al. 2014).

TABLE 1. Comparison of UV-Vis absorption peak in the presence of different chemical reducing agent

\begin{tabular}{|c|c|c|c|c|}
\hline Method & $\begin{array}{c}\text { Reducing } \\
\text { agent }\end{array}$ & $\begin{array}{l}\text { Graphene } \\
\text { peak }(\mathrm{nm})\end{array}$ & $\begin{array}{c}\text { Plasmon peak } \\
(\mathrm{nm})\end{array}$ & $\begin{array}{c}\text { Graphene peak } \\
\text { shifting }(\%)\end{array}$ \\
\hline GO (this work) & - & 228 & - & - \\
\hline Ag-rGO (this work) & - & 230 & 398 & 0.9 \\
\hline Sonochemical (Golsheikh et al. 2014) & - & 251 & 396 & 10.1 \\
\hline Chemical synthesis (Sahu et al. 2013) & Hydrazine & 260 & 420 & 14 \\
\hline Chemical synthesis (Liu et al. 2015) & Ascorbic acid & 264 & 408 & 15.8 \\
\hline Sonochemical and annealing (Dinh et al. 2014) & Ascorbic acid & 238 & 418 & 4.4 \\
\hline Ag-rGO-AA (this work) & Ascorbic acid & 271 & 424 & 18.9 \\
\hline
\end{tabular}


Table 1 shows the comparison of the UV-vis absorbance peaks in the presence of different reducing agent. Commonly, hydrazine is being used to reduce GO despite its toxicity. Gao et al. (2010b) concluded from their work that hydrazine can only reduce epoxy and hydroxyl groups located at the interior of an aromatic domain, which makes it a less effective reducing agent. Sahu et al. (2013) reported the observation of absorption peak at $260 \mathrm{~nm}$ in GO sample reduced by hydrazine. Remarkably, $271 \mathrm{~nm}$ was obtained using ascorbic acid in this work. This suggests that an ascorbic acid can reduce both epoxy and hydroxyl groups in GO as effective as $18.9 \%$ compared to hydrazine (14\%).

Figure 4 shows the FESEM images of Ag-rGO and Ag-rGO-AA nanocomposite. The surface of the Ag-rGO nanocomposite shows the stacking sheets of Ag-rGO with flat morphology. For Ag-rGO-AA nanocomposite, the stacking sheets of rGO show crumpled silk-like morphology with the increase of AgNPs size. The increase of AgNPs size after the introduction of ascorbic acid is also consistent with the characteristics shown in the UV-Vis spectra.

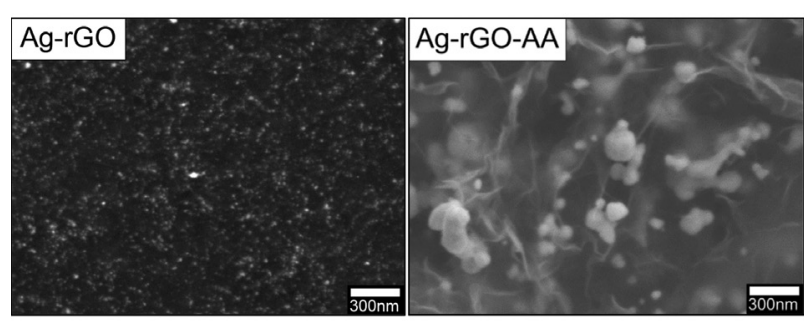

FIGURE 4. FESEM images of (a)Ag-rGO and

(b)Ag-rGO-AA nanocomposite

Figure 5 shows the Raman spectra of GO and AgrGO-AA. Typically, the Raman spectra of GO show the peak of D band at approximately $1342 \mathrm{~cm}^{-1}$ and the $\mathrm{G}$ band at approximately $1580 \mathrm{~cm}^{-1}$. The $\mathrm{G}$ band is related to $\mathrm{sp}^{2}$ hybridized C-C bonds which explains the first-order scattering of the $\mathrm{E}_{2 \mathrm{~g}}$ phonon in graphene. The prominent $\mathrm{D}$ peak corresponds to the structural imperfections generated by the attachment of hydroxyl and epoxide group on the carbon basal plane (Huang et al. 2013). The ratio of the intensities of the $\mathrm{D}$ band and $\mathrm{G}$ band, $\mathrm{I}_{\mathrm{D}} / \mathrm{I}_{\mathrm{G}}$ were calculated. The $\mathrm{I}_{\mathrm{D}} / \mathrm{I}_{\mathrm{G}}$ ratio for $\mathrm{GO}$ is estimated to be around 1.03 and for Ag-rGO-AA is around 1.30. This increase seems to represent the increase of the number of small $\mathrm{sp}^{2}$ domains, the presence of unrepaired defects that remain after the removal of large amounts of O-containing functional groups and the restoration of the $\mathrm{sp}^{2}$ network (Feng et al. 2013; Liu et al.2015). The results are also consistent with the characteristics shown in the FTIR spectra.

Figure 6 illustrates the possible two formation routes of functional groups on $\mathrm{C}=\mathrm{C}$ bond during the oxidation process. First, the epoxide is formed on $\mathrm{C}=\mathrm{C}$ bond in graphite by the oxidation in $\mathrm{KMnO}_{4}$ (top schematic) and

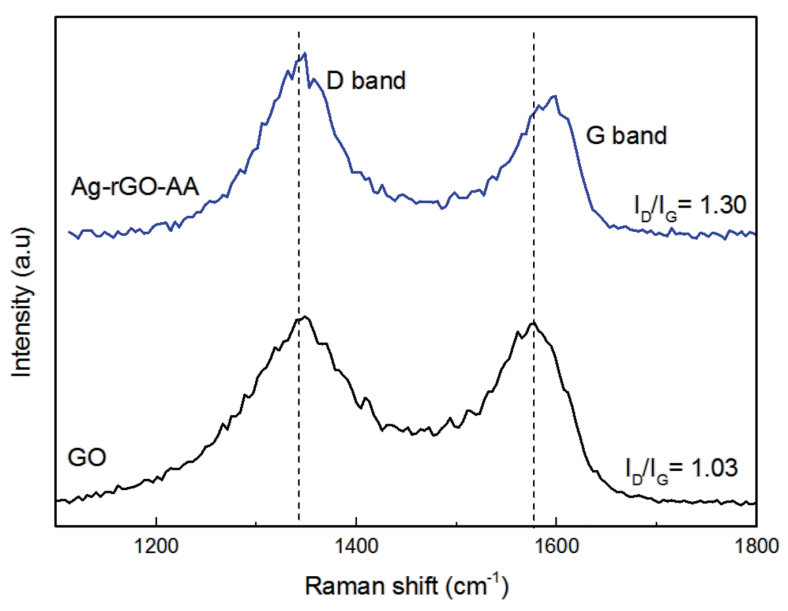

FIGURE 5. Raman spectra of GO and Ag-rGO-AA nanocomposite

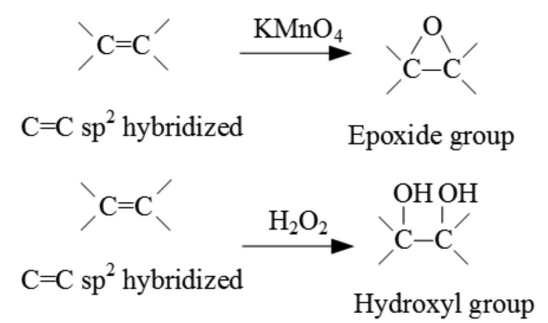

FIGURE 6. Formation of functional groups on $\mathrm{C}=\mathrm{C}$ bond during the oxidation process

second, the hydroxyl is formed by the oxidation in $\mathrm{H}_{2} \mathrm{O}_{2}$ (bottom schematic) (Garcia-Bosch et al. 2009; Wiberg \& Saegebarth 1957).

Figure 7 shows the chemical reaction between oxygen (O)-containing functional groups on the GO sheets, i.e. epoxide and hydroxyl groups and ascorbic acid in order to enhance the reduction of GO (Xu et al. 2015). Both hydroxyl and epoxide groups were decomposed upon reaction with hydrogen $(\mathrm{H})$ atoms in the five pentagonal ring of ascorbic acid to form the rGO with high quantity of $\mathrm{C}=\mathrm{C}$ bonds with both water $\left(\mathrm{H}_{2} \mathrm{O}\right)$ and dehydroascorbic acid as side products. The formation of $\mathrm{C}=\mathrm{C}$ bonds without any attachment of functional group indicates the enhanced reduction of GO sheets as evidenced by UV-Vis and FTIR data.

\section{CONCLUSION}

The epoxide and hydroxyl functional groups are formed on $\mathrm{C}=\mathrm{C}$ bond in graphite during the oxidation process. Both were effectively decomposed upon reaction with $\mathrm{H}$ atoms in the five pentagonal ring of ascorbic acid to form highly reduced GO. For Ag-rGO-AA composite, no significant reflectance peak which corresponds to functional group is observed, suggesting a nearly complete removal of O-containing groups from the GO sheets by the addition 


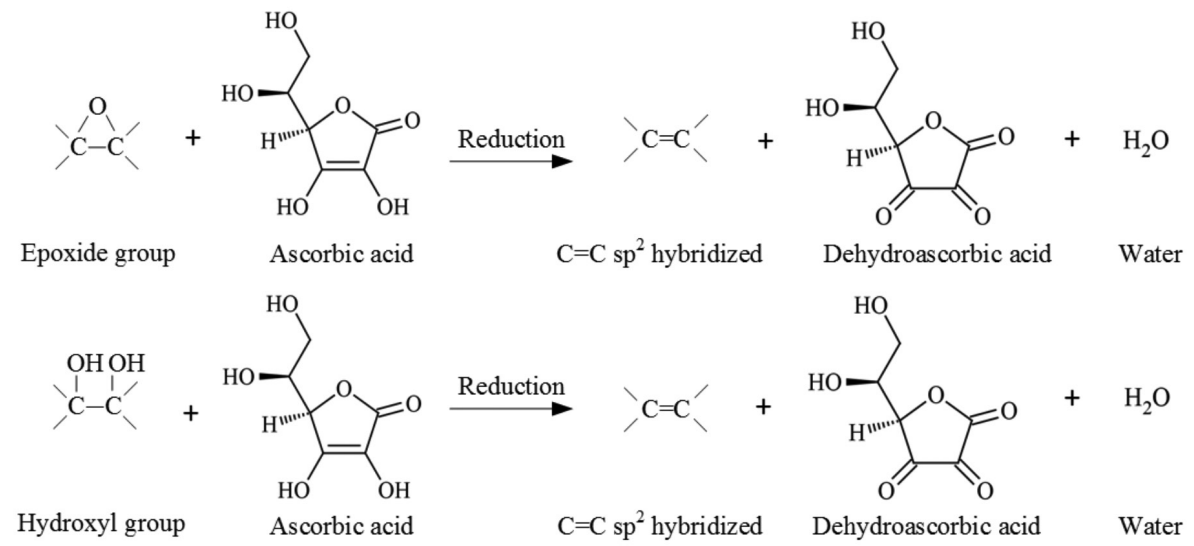

FIGURE 7. Interaction of functional groups with ascorbic acid during the reduction process

of ascorbic acid. The observation of weak reflectance peak which corresponds to $\mathrm{C}=\mathrm{C}$ bond can be explained by the bond polarity effect. The red shifting of $\mathrm{C}=\mathrm{C}$ bond indicates the rapid occurrence of electronic conjugation. The red shifting of AgNPs peak is related to the increase of AgNPs size. The increase in $\mathrm{I}_{\mathrm{D}} / \mathrm{I}_{\mathrm{G}}$ ratio after the introduction of ascorbic acid may represent the increase of the number of small $\mathrm{sp}^{2}$ domains, the presence of unrepaired defects that remain after the removal of large amounts of $\mathrm{O}$-containing functional groups and the restoration of the $\mathrm{sp}^{2}$ network. High reduction of AgNPs-rGO sheets using non-toxic and environmental-friendly reducing agent was achieved.

\section{ACKNOWLEDGEMENTS}

N.S.A. Aziz and M.K.N. Azmi thank the Malaysia-Japan International Institute of Technology and Malaysia Ministry of Education for the scholarships. This work was funded by Universiti Teknologi Malaysia and the Ministry of Education, Malaysia through various research grants.

\section{REFERENCES}

Abulizi, A., Okitsu, K. \& Zhu, J-J. 2014. Ultrasound assisted reduction of graphene oxide to graphene in 1-ascorbic acid aqueous solutions: Kinetics and effects of various factors on the rate of graphene formation. Ultrasonics Sonochemistry 21(3): 1174-1181.

Cui, S., Mao, S., Wen, Z., Chang, J., Zhang, Y. \& Chen, J. 2013. Controllable synthesis of silver nanoparticle-decorated reduced graphene oxide hybrids for ammonia detection. Analyst 138(10): 2877-2882.

Dinh, D.A., Hui, K.S., Hui, K.N., Cho, Y.R., Zhou, W., Hong, X. \& Chun, H-H. 2014. Green synthesis of high conductivity silver nanoparticle-reduced graphene oxide composite films. Applied Surface Science 298: 62-67.

Feng, H., Cheng, R., Zhao, X., Duan, X. \& Li, J. 2013. A lowtemperature method to produce highly reduced graphene oxide. Nature Communications 4: 1539. DOI: 10.1038/ ncomms 2555 .

Gao, J., Liu, F., Liu, Y., Ma, N., Wang, Z. \& Zhang, X. 2010a. Environment-friendly method to produce graphene that employs vitamin $\mathrm{C}$ and amino acid. Chemistry of Materials 22(7): 2213-2218
Gao, X., Jang, J. \& Nagase, S. 2010b. Hydrazine and thermal reduction of graphene oxide: reaction mechanisms, product structures, and reaction design. Journal of Physical Chemistry C 114(2): 832-842.

Garcia-Bosch,I., Ribas, X.\& Costas, M. 2009. A broad substratescope method for fast, efficient and selective hydrogen peroxide-epoxidation. Advanced Synthesis \& Catalysis 351(3): 348-352.

Golsheikh, A.M., Huang, N.M., Lim, H.N. \& Zakaria, R. 2014. One-pot sonochemical synthesis of reduced graphene oxide uniformly decorated with ultrafine silver nanoparticles for non-enzymatic detection of $\mathrm{H} 2 \mathrm{O} 2$ and optical detection of mercury ions. RSC Advances 4(69): 36401-36411.

He, D., Shen, L., Zhang, X., Wang, Y., Bao, N. \& Kung, H.H. 2014. An efficient and eco-friendly solution-chemical route for preparation of ultrastable reduced graphene oxide suspensions. AIChE Journal 60(8): 2757-2764.

Huang, N.M. 2011. Simple room-temperature preparation of high-yield large-area graphene oxide. International Journal of Nanomedicine 6: 3443-3448.

Huang, Y., Liu, P. \& Wang, L.E.I. 2013. Production of stable dispersions of reduced graphene oxide using indole as a reduction agent. Nano 08(02): 1350017.

Li, X., Zhang, G., Bai, X., Sun, X., Wang, X., Wang, E. \& Dai, H. 2008. Highly conducting graphene sheets and LangmuirBlodgett films. Nature Nanotechnology 3(9): 538-542.

Liu, J., Liu, L., Wu, X., Zhang, X. \& Li, T. 2015. Environmentally friendly synthesis of graphene-silver composites with surfaceenhanced Raman scattering and antibacterial activity via reduction with 1-ascorbic acid/water vapor. New Journal of Chemistry 39(7): 5272-5281.

Norhakim, N., Ahmad, S.H., Chia, C.H. \& Huang, N.M. 2014 Mechanical and thermal properties of graphene oxide filled epoxy nanocomposites. Sains Malaysiana 43(4): 603-609.

Paramelle, D., Sadovoy, A., Gorelik, S., Free, P., Hobley, J. \& Fernig, D.G. 2014. A rapid method to estimate the concentration of citrate capped silver nanoparticles from UV-visible light spectra. Analyst 139(19): 4855-4861.

Pumera, M. 2010. Graphene-based nanomaterials and their electrochemistry. Chemical Society Reviews 39(11): 41464157.

Sahu, S.R., Devi, M.M., Mukherjee, P., Sen, P. \& Biswas, K. 2013. Optical property characterization of novel graphene-X $(\mathrm{X}=\mathrm{Ag}, \mathrm{Au}$ and $\mathrm{Cu})$ nanoparticle hybrids. Journal of Nanomaterials 2013: Article ID. 232409. 
Vollhardt, P. \& Schore, N.E. 2009. Organic Chemistry: Structure and Function. 6th ed. New York: W.H. Freeman

Wiberg, K.B. \& Saegebarth, K.A. 1957. The mechanisms of permanganate oxidation. IV. hydroxylation of olefins and related reactions. Journal of American Chemical Society 79(11): 2822-2824.

Xu, B., Xu, C., Shi, X., Ji, A., Shi, L., Zhou, C. \& Cui, Y. 2015. Fabrication and characteristics of reduced graphene oxide produced with different green reductants. Plos One 10(12): $\mathrm{e} 0144842$.

Zacharia, R., Ulbricht, H. \& Hertel, T. 2004. Interlayer cohesive energy of graphite from thermal desorption of polyaromatic hydrocarbons. Physical Review B 69(15): 155406.

Zhang, Y., Liu, S., Wang, L., Qin, X., Tian, J., Lu, W., Chang, G. \& Sun, X. 2012. One-pot green synthesis of Ag nanoparticlesgraphene nanocomposites and their applications in SERS, $\mathrm{H} 2 \mathrm{O} 2$, and glucose sensing. RSC Advances 2(2): 538-545.

Zhou, Y., Yang, J., Cheng, X., Zhao, N., Sun, H. \& Li, D. 2013. Transparent and conductive reduced graphene oxide/silver nanoparticles multilayer film obtained by electrical selfassembly process with graphene oxide sheets and silver colloid. RSC Advances 3(10): 3391.
Malaysia-Japan International Institute of Technology Universiti Teknologi Malaysia

Jalan Sultan Yahya Petra

54100 Kuala Lumpur, Federal Territory

Malaysia

*Corresponding author; email: abdmanaf@utm.my

Received: 26 December 2016

Accepted: 27 January 2017 